\title{
British doctors' experiences of working in rural South Africa: The London GP Out of Programme Experience
}

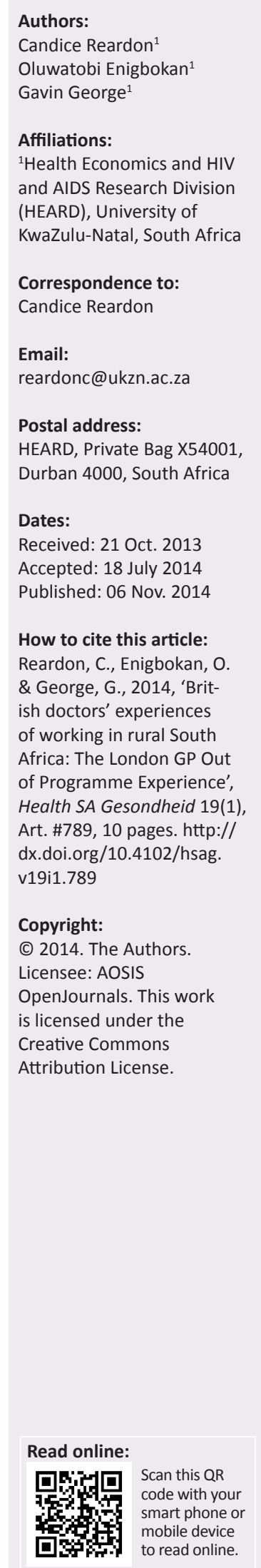

Background: A paucity of research exists that has examined temporary placements of foreign health professionals in South Africa (SA) as a possible strategy for addressing health worker shortages. The Out of Programme Experience (OOPE) initiative, run by the London GP Deanery, aims to provide a sustainable inflow of British, trainee GP doctors into rural public health facilities in SA.

Objectives: The present study explored the experiences of these British doctors working in rural hospitals in SA as part of their OOPE. The reasons and motivations underlying their decision to come to SA were also examined.

Methods: In-depth interviews were conducted with fifteen British doctors who were currently working, or had worked in the past, as part of OOPE in rural health facilities in SA. Interviews were transcribed and analysed using thematic analysis.

Results: The first theme that surfaced from the interviews was that the most common reasons underlying these doctors' motivations for coming to SA related to: the type of diseases and advanced pathologies that they would encounter; the challenge and opportunity for professional growth; and the difference in work environment that would confer on them greater responsibility and autonomy, compared to working in similar positions in the British National Health Service. The second theme, central to the participants' narratives, was the accelerated period of learning that they experienced whilst in SA. Exposure to new and unfamiliar medical cases, a greater level of autonomy and decision-making authority, and resource shortages forced greater reliance on their clinical skills and judgment, which contributed to their professional development.

Conclusion: The doctors' believed the OOPE enhanced their clinical skills and competencies. The findings provide some evidence that attests to the OOPE's potential to benefit both host facilities and the participating foreign doctors. The findings of the study have practical implications for the further development of programmes to fill vacant posts for health workers in rural South African hospitals.

Agtergrond: Daar bly 'n gebrek aan navorsing met betrekking tot tydelike posisies vir buitelandse professionele gesondheidswerkers in Suid-Afrika (SA) as 'n moontlike strategiese oplossing vir die tekort aan gesondheidswerkers in die land. Die 'Out of Programme Experience' (OOPE) inisiatief, wat deur die 'London GP Deanery' georganiseer word, se doel is om 'n volhoubare invloei van Britse dokters-in-opleiding aan plattelandse openbare gesondheidsfasiliteite te voorsien.

Doelwitte: Hierdie studie het die ervarings van hierdie Britse dokters, wat as deel van die OOPE-program in plattelandse Suid-Afrikaanse hospitale gewerk het, verken. Die onderliggende redes en motivering vir hul besluite om na Suid-Afrika toe te kom, is ook ondersoek.

Metodes: In-diepte onderhoude is met 15 Britse dokters gevoer wat huidiglik, of in die verlede, in plattelandse gesondheidsfasiliteite in SA gewerk het as deel van die OOPEprogram. Die onderhoude is getranskribeer en tematiese analise is gebruik om dit te analiseer.

Resultate: Die eerste tema wat uit die onderhoude geïdentifiseer is, is dat die mees algemene redes hoekom hierdie dokters na SA gekom het verband hou met die tipe siektes en gevorderde patologie wat hulle in SA sou teëkom. Die tweede tema wat geïdentifieer is, is die versnelde leerkurwe wat hulle ervaar het in SA.

Gevolgtrekkings: Die dokters het geglo dat die OOPE-program hul kliniese vaardighede verbeter het. Hierdie studie getuig van die OOPE se potensiaal om beide die plaaslike gesondheidsfasiliteite sowel as die deelnemende buitelandse dokters te bevoordeel. Die gevolgtrekkings van die studie het praktiese implikasies vir die verdere ontwikkeling van programme om vakante poste vir gesondheidspersoneel in plattelandse hospitale in SA te vul. 


\section{Introduction \\ Problem statement}

Many studies have revealed a shortage of doctors and nurses in South Africa (SA) (Clemens \& Pettersson 2008; Delobelle et al. 2011). Comparing the staffing of doctors and nurses in SA with six peer countries of similar Gross Domestic Product (GDP), growth rate and population size, SA has the lowest number of health professionals; it would require up to 60000 additional doctors in the coming years for it to equal the doctor-to-patient ratio of Brazil (Department of Health 2011).

The need for strategies to alleviate health worker shortages is urgently required (Mills et al. 2011; George et al. 2012; Essack 2013). Strategies to bridge the human resource for health (HRH) shortfall through promoting the retention of health workers, especially in rural areas of SA, are particularly important (Kingma 2008; Bangdiwala et al. 2010; Mills et al. 2011; Faye et al. 2013). Drawing less attention from researchers are the strategies and initiatives to bring foreign doctors into developing countries that are grappling with HRH shortages. The Out of Programme Experience (OOPE), the focus of the present study, aims to provide a viable means of alleviating $\mathrm{HRH}$ shortages brought about by emigration and internal migration.

Generally, doctors working outside their countries are faced with new experiences of a healthcare system operating in other nations. Doctors who have had this opportunity, more especially those working in rural areas in other countries, have experienced increased responsibilities in rural facilities (Jacques et al. 1998). To meet with these expectations, doctors have had to adapt and hone their medical skills in a much shorter period of time.

In South Africa, whilst procedural, bureaucratic requirements for the registration of foreign doctors has already been seen to be problematic and time-consuming (Reid 2001), once accepted, many British doctors are often posted to remote district hospitals in different provinces and are expected to perform generalist functions.

\section{Research aims and objectives}

A paucity of research exists that has examined effective temporary placements of foreign $\mathrm{HRH}$ in SA as a possible strategy for addressing health worker shortages (IOM 2011). The OOPE, which is run by the London GP Deanery in partnership with Africa Health Placements (AHP), sets out to improve shortages of medical doctors in rural areas of SA by providing an annual inflow of foreign-trained doctors to rural health facilities.

The present study documents British, trainee GP doctors' reasons for coming to SA and their experiences whilst working at rural hospitals during their OOPE. The concept of 'doctors' used throughout in this article refers to the participants of the study.

\section{Literature review}

Although the contingent of doctors and nurses in SA exceeds the World Health Organization's (WHO) minimum requirements of 20 medical doctors and 120 nurses per 100000 people (WHO 2006), SA has a far lower doctor-topopulation ratio (62:100 000) compared to other middleincome countries such as Mexico (198 per 100 000) and Brazil (185 per 100 000) (Econex 2010). According to data from the Personnel and Salary Administration System in SA, national vacancy rates for 2010 amongst general practitioners $(49.0 \%)$, specialist doctors $(44.0 \%)$, and other health professionals $(42.5 \%)$ showcase the numerical shortage of health staff in the public service (George et al. 2012). Rural provinces such as Limpopo (68\%), Eastern Cape $(59 \%)$ and Free State $(47 \%)$ have demonstrated higher vacancy rates of healthcare professionals than the country's average in recent years (Econex 2010; Department of Health 2011; Moloi 2013). In comparison, the proportion of doctors in the private health sector has increased significantly from $40 \%$ in 1980 to $79 \%$ in 2007 (Lloyd et al. 2010). However, thinking about the shortage of healthcare personnel in the public sector solely in terms of insufficient numbers will not produce effective strategic interventions to solve the country's HRH problem. Researchers have argued that strategies to address the shortage of health workers in SA need to take into account the maldistribution of HRH (Dovlo 2007; Witt 2009), the attrition of staff from the public health services and, contextually, the ever-changing demands on the health services (George et al. 2012).

\section{Emigration of human resource for health (HRH) in SA}

According to some authors, factors contributing to attrition in the public health sector in SA seem to be to HIV and/or AIDS and migration. The loss of health-sector staff through emigration is well documented (Hamilton \& Yau 2004; Breier \& Wildschut 2006; Sanders \& Lloyd 2009), whilst the attrition of healthcare professionals as a result of the fear of occupational transmission of HIV and/or AIDS has been alluded to by Bezuidenhout et al. (2009). The latter has also been associated with reduced workforce motivation and on-the-job performance in the face of resource shortages and poor coping mechanisms (Dovlo 2007). Many of the health professionals have, for example, to assist with Voluntary Counselling and Testing (VCT) and antiretroviral treatment (ART) distribution and/or rationing (Rosen et al. 2005; Tawfik \& Kinoti 2006), which strains their already loaded work schedules and leads to stress-related and work-related illnesses (Awases et al. 2004; Shisana et al. 2004). Burnout occurs as a result of the excessive workload that healthcare professionals have to face (Kinoti 2003; Shisana et al. 2004). Countries that are hardest hit by the HIV / AIDS epidemic experience huge personnel shortages because some healthcare professionals revert to non-clinical professions, or end up exiting the health service to work in environments that they feel are safer (Tawfik \& Kinoti 2006; Dovlo 2007). 
It has been estimated that by 2015, SA will experience a critical gap of 15380 staff nurses, 22121 professional nurses, 3930 doctors and 5677 medical specialists (WHO 2006). The shortage of nurses also affects the delivery of healthcare by doctors, and it is of note that $5.0 \%$ of SA-born nurses live and work outside of the country (Wildschut \& Mgqolozana 2009). In addition, South African doctors are highly concentrated in English speaking, first world countries (Breier et al. 2009). Long (2007) calculated that South African doctors comprised $9.7 \%$ and $7.0 \%$ of the foreign-trained doctor workforces in Australia and the UK, respectively. Recent estimates suggest that in 2010, about 29.4\% (12 108) of physicians trained in SA had emigrated (Tjadens et al. 2012).

In addition to HRH that have left SA, evidence shows that a substantial number of health workers in the country are considering emigration. A recent study amongst medical and nursing students found that $37.0 \%$ of respondents planned to seek employment abroad after completion of their studies, the majority of who were planning to emigrate within five years of graduation (George \& Reardon 2013). This consistent exodus of $\mathrm{HRH}$ erodes the medical skills base of the country, and contributes to the specific skills and geographical shortages of health workers (George et al. 2009; George \& Reardon 2013).

\section{Bilateral agreements and other programmes to bring foreign HRH to SA}

South Africa has entered into a number of bilateral agreements with foreign governments, which are aimed at moderating the outflow of South African HRH and alleviating health worker shortages (Stilwell et al. 2004). The bilateral agreement between the United Kingdom (UK) and SA, and the Commonwealth Code of Practice for the International Recruitment of Health Workers have, for example, played an important role in reducing the significant out flow of South African HRH to the UK in earlier years. The bilateral agreements between the South African government and Tunisia and Cuba (Hontelez et al. 2012) have played a role in strengthening rural healthcare systems weakened by migration. South Africa's co-operative agreement with Tunisia was signed in 1999 and reaffirmed in 2004. In 2007, a technical agreement was signed with the Tunisian government whereby 258 Tunisian doctors were selected for deployment to SA (George et al. 2009). An agreement with the Iranian government brought 36 experienced Iranian doctors to SA in 2006, with a further 100 earmarked for local deployment at that time (George et al. 2009).

In addition to these bilateral agreements, other programmes exist that bring medical professionals from foreign countries to work in SA. One such example is the OOPE, which is run by the London GP Deanery and Africa Health Placements (AHP), a social profit organisation based in Johannesburg. The OOPE allows for doctors specialising in family medicine (qualified general practitioners two years into their four-year family medicine resident training) to gain clinical experience for one year in a rural, under-served public hospital in
KwaZulu-Natal or the Eastern Cape, after which they will return to a guaranteed post to continue their third year (ST3) of specialist training in the UK. The process of arranging for the Deanery candidates to come to South Africa is facilitated by AHP and two co-ordinators: one based in the UK and one in South Africa. The hospitals to which they are allocated employ the candidates as medical officers for one year, with the local department of health paying their salaries.

The OOPE programme was established with two objectives in mind: to provide a sustainable inflow of British doctors, specialising in family practice, into rural health facilities in SA; and to hold significant benefit for the professional development of the participating British doctors themselves. The programme was developed on the premise that the current three-year family medicine specialist-training programme provides limited time to fulfill all of the training requirements of the Royal College of General Practitioners' curriculum. It is believed that the OOPE can provide these doctors with the skills and competencies that they require for their specialist training, whilst also offering them international experience.

Implementing the OOPE also requires a system with which to assess the quality of work provided by participants at the various service delivery sites. E-portfolios provide some basis for this checking of what the doctors have learnt, and this is assessed each month by the educational supervisors in London assigned to the doctors. After the first six months, reviews are conducted with the trainee doctors; these reviews usually last two hours. A national clinical supervisor in the destination country provides supervision at the designated rural hospitals for each trainee doctor. E-portfolios have to be signed off by the clinical supervisor as a way of controlling the quality of each doctor's service delivery and providing evidence of the work being done by the doctors at their assigned hospitals.

\section{Research Methods Design and sample}

The present study is based on the findings of a qualitative, phenomenological enquiry conducted between October 2010 and February 2011. A total of fifteen British doctors, who were participating in the OOPE programme, were interviewed for the study. This figure included nine doctors who were in SA at the time as part of the programme, the partners of two of the Deanery candidates who were also medical doctors taking a year out of the specialist training programmes to work in rural health facilities, and four ex-Deanery candidates who had been on the OOPE the previous year. Therefore, these participants included all of the British doctors who participated in the OOPE between 2009 (the year of its inception) and 2010.

\section{Research setting}

All of the participants worked in local district, rural hospitals: thirteen in the province of KwaZulu-Natal and 
two in the Eastern Cape. These district hospitals usually have a 30-bed to 200-bed capacity, and generally provide: integrated primary healthcare services to communities; general services to patients who are usually referred from community health clinics; the entry point to specialist care; and 24-hour emergency services (Department of Health 2002; Cullinan 2006).

\section{Research instruments}

Two semi-structured interview schedules were used: one with the 2011 cohort of Deanery candidates in SA at the time, and the other with the 2010 cohort of Deanery candidates back in the UK. The semi-structured interview schedules were similar, yet the one developed for the 2010 Deanery candidates was able to probe more deeply into the benefits of the OOPE for the doctors after their return to the UK.

The questions contained in the interview schedules covered the following: their reasons for coming to SA and doing the OOPE; the process of preparation for the OOPE; their expectations; their experiences of living and working in SA; their goals and aims for the OOPE; the benefits and values that they derived from it; their views and opinions about the structure of the programme; and their future career plans. The paper reports on the data gathered on participants' reasons for coming to SA and on their experiences of working in SA.

\section{Data collection}

Interviews with the British doctors lasted between 30 min $45 \mathrm{~min}$ per session and were conducted by the same fieldworker: a female, junior researcher with experience in qualitative data collection. Interviews with those doctors based in the UK $(n=4)$ and one who was based in the Eastern Cape were conducted telephonically. The remainder of the interviews $(n=9)$ were conducted face-to-face with the participants at their places of employment. All of the interviews were tape recorded and transcribed verbatim.

\section{Data analysis}

The process of analysing the data was guided by the methodology of thematic analysis outlined by Gibbs (2007), and Ryan and Bernard (2003). As recommended by Bogdan and Biklen (1982), the transcripts were read twice by the researcher to familiarise herself with the data. The coding was data-driven as themes were allowed to emerge from the text. Opler's terminology of 'expressions' and 'themes' was used in coding the data (1945, cited in Ryan \& Bernard 2003). 'Expressions' denote the basic units of data or incidents in the text that through a process of synthesising and comparison across cases develop into themes and subthemes. The researcher began by using descriptive codes to identify basic expressions that were found in individual transcripts. These were compared with other expressions emerging from other interviews, and through comparing and synthesising these expressions were categorised into sub-themes and given more analytical coding labels. Hence, the process of analysing the data moved from descriptive to analytical coding, as recommended by Gibbs (2007). Ryan and Bernard's (2003) techniques for identifying themes from basic expressions in the text were used to guide the process through which sub-themes were identified from the text, which enhanced the reliability of the findings.

\section{Results}

In line with the aims of the present study, the content of the results will focus on two main themes: (1) the doctors' reasons for coming to SA for the OOPE, and (2) their experiences of working in SA.

Theme 1: Reasons given by British doctors for coming to SA through the OOPE: Many of the doctors had already worked in Africa through: volunteer activities and aid work; elective courses as part of their medical degree; or regular, paid medical work. Doctors with previous international work experience strongly believed that time spent working abroad held value for both professional and personal development, helping them to become 'better, well-rounded individuals'. In the following quote, one doctor alluded to the professional motives behind his decision to embark on the OOPE:

'There were still areas in my knowledge base, which I felt I could expand upon. Being a general practitioner essentially you need to be able to do a bit of everything. And there were areas that I haven't had a lot of clinical experience with ... so this is an opportunity for me to get more experience in that.' (Male doctor, northern $\mathrm{KZN}$ )

The OOPE was seen as a 'challenge' by doctors who wanted to gain experience in medical problems typically seen in a developing nation context, more advanced clinical pathologies, and a different healthcare system. The context of rural SA itself was a draw card for some doctors who described it as a 'mix of first-world healthcare and thirdworld problems'. Four doctors expressed views that medical experience outside of the National Health Service (NHS) was beneficial, owing to its heavily structured learning and work environment that could stifle their professional development.

The desire to be excited, inspired and challenged in their career also influenced their decision to work abroad. Several doctors referred to the challenge of working in this new environment as 'putting myself in the deep end', an 'adventure' and 'exhilarating'. In the following quote, a doctor shared how the sense of excitement of working in a rural hospital and the challenge of facing unfamiliar and difficult medical cases was integral to her decision to come to SA:

'It's just such an exciting concept to come to somewhere like rural SA and work in a hospital where anything and everything can and does come through the door ... It's about challenging myself as well. You can become very set in structure in the way training programmes work back home and doing something like this can give me a bit more freedom and bit more inspiration as well.' (Female doctor, northern KZN) 
Theme 2: Experiences of British doctors working in SA: 'A constant process of learning': Doctors' narratives of their work experience in rural health facilities in SA were often described in relation to the learning experience it afforded them. This experience often entailed assuming positions of various levels of seniority at different times.

Taking on multiple roles: 'The consultants, registrars and junior doctors all rolled into one': In many of the interviews, the doctors spoke of having to adjust to a different culture of working relationships. This stemmed, in part, from a structure of relationships that was far less hierarchical compared to the NHS in the UK. This resulted in them adopting multiple roles in their day-to-day responsibilities. One doctor emphasised that his dual role required him to be a team player; whilst at other times, it was necessary for him to be a leader. Another doctor explained that whilst on call, he became the senior person with whom the responsibility rested, whilst during his day-to-day activities there would be no differentiation in roles as he worked alongside his subordinates. In terms of 'taking on a specialist role', one doctor described how the treatment of certain HIV-related diseases he was managing at his rural hospital would be handled at the consultant level in the UK:

'So you get things like cryptococo [Cryptococcus] meningitis, which is an HIV-related disease. We'll have on average two or three on the ward at any one time and we'll be managing them. Back home that will be at a super specialist center . . . and a generalist like me will have next to nothing to add to their care.' (Male doctor, northern KZN)

In the following excerpt, another doctor who felt that he was taking on a specialist role also described his experience in SA in comparison to how the health system works in the UK:

'I feel like I'm moving into specialist territory. Back in the UK you wouldn't do a caesarean section unless you're an obs and gynae [Obstetrician and Gynaecologist] specialist doctor. Here I had training for about three or four weeks and we're doing caesarean sections ourselves now. And also back home we wouldn't be expected to make the call for someone to have a caesarean section or not, whereas here I run the high-risk clinic.' (Male doctor, inland KZN)

In addition to developing specialist skills, the doctors were being given opportunities to develop generalist skills. Being put on rotation in different wards exposed them to a wide variety of unfamiliar medical cases and gave them the opportunity to develop skills as diverse as working in paediatrics, performing male circumcision and interpreting ultrasound scans.

The opportunity to take on a larger amount of responsibility and manage difficult patient cases was described as 'exhilarating'. Approximately half of the sample highlighted the learning opportunities that were afforded to them due to the greater level of autonomy and responsibility they had in their work environment. For four doctors, this involved formalised learning opportunities with senior staff who taught them particular medical procedures and new skills.
One of the doctors reflected positively on this learning experience, as evidenced by the following response:

'It's really good to be pushing yourself again and learning something new and then you sit back and you think, "Gosh I've done this and I've done that. I would never have done that in the UK" .. . They (the NHS) were slowly increasing my skills but nothing like what we've done here ... It makes you very proud of yourself and to want to keep pushing myself to do these things.' (Female doctor, rural hospital, inland KZN)

Sub-theme 2.1 Learning to cope: 'Learning to cope' was a central theme of the doctors' work experiences that emerged from almost every interview. Some doctors demonstrated positive cognitive responses to challenges in their work environment that facilitated their adaptation. For instance, several doctors reported a high level of internal confidence in their ability to deal with challenging and even unfamiliar circumstances. They appeared to approach such situations with an optimistic and problem-solving orientation that was highly beneficial to their coping.

Their experience of learning to cope with challenges was often couched in the phrase 'having to make a plan'. This expression referred to situations where the doctors did what was required, within their means, to rise to the challenge of what they were being faced with. This is articulated in the following quote:

'You end up deciding what you've got to do just to get through the day, get through the week in terms of resources, the medication, the equipment . . . that was quite hard, but again we just all used to sit down and make a plan and decide what we had to do, what we couldn't do, what we could do.' (Female doctor, northern KZN, 2010 Deanery candidate)

Two doctors shared very concrete experiences of instances where they had been forced to 'make a plan'. For one doctor, a severe motor vehicle accident had resulted in her emergency room being filled with patients; she described it as 'managing a small disaster', which she found 'quite satisfying'. Similarly, another doctor who had been forced to engage in a crash course of Zulu during the health worker strike that left her with no translator, expressed a similar positive sentiment about her experience of 'making a plan', which she described as 'quite fun'.

Several doctors were planning to, or currently used, constructive strategies to deal with problems and issues they were not content with at their hospitals. Five doctors had sought to address their frustrations about bad medical practices through raising these problems at staff meetings, giving presentations to staff and engaging in 'on the job' training with staff. Another doctor initiated antiretroviral treatment (ART) with children whilst they were in the ward, because of the delays initiating children on ART through the primary healthcare clinics. Another doctor was attempting to bring in a more evidence-based approach to medicine. One doctor had set up a research study at her hospital to investigate the practice of traditional enemas in babies, which was prevalent in the community. In contrast, 
in situations where it was not within their ability to address the problem, doctors used their internal coping skills. This entailed finding ways of coping with their frustrations, such as through changing their perspective, and accepting the way that things are done in their health facility.

Sub-theme 2.2 Dealing with resource shortages: The majority of the doctors spoke of having huge staff shortages in the rural hospitals. The resource shortages left the doctors feeling stressed and depressed. Despite having worked within this resource-limited context for several months prior to the interview, the reality of the resource shortages was still perplexing to some doctors. Staff shortages made several of the doctors come to think of themselves as a 'resource' that needed to be preserved, as noted in the following excerpt:

\begin{abstract}
'You are a resource ... do I get out of bed every time they call me for anything? Or do I say 'right, can you give them this, this and this and I'll see them in four hours in the morning'. Somebody has to do that and make those sorts of resource decisions, when that probably isn't the best for the patient but you won't function anymore and the next 40 patients you see, you're not going to be functional . . I'm a bit frightened about how I've got used that.' (Female doctor, northern KZN)
\end{abstract}

Five doctors recounted stories where they were responsible for making choices that meant life or death decisions for their patients. They explained, as in the following quote, how in their treatment decisions they weighed up the patients' HIV status and the probability of recovery:

'Perhaps the most difficult choices I have to make at XXX are the ones where I know the resources are limited and I have patients competing for them ... I suddenly have to take into account factors such as their HIV status and their relative chances of a positive outcome, playing judge and jury.' (Male doctor, northern $\mathrm{KZN}$ )

In addition to wisely making difficult decisions to ration resources, several doctors also experienced distress in having to carry out decisions from superiors that meant depriving some patients of quality care. In the quote below, one of the doctors was absolved of the need to make the difficult decision about a patient's life, but the reality of having to execute the decision was equally distressing for her:

'I phoned my other doctor colleague and said "Right, this person needs to be intubated and we need to ventilate her" ... And he said no one will take an HIV-positive patient to be ventilated . . . so I watched her die ... You know as a doctor that's not what I got into it for.' (Female doctor, northern KZN)

Sub-theme 2.3 Frustrating experiences: The majority of the doctors described their negative experiences as 'frustrations' rather than definitively negative experiences. Common frustrating experiences were associated with: (1) the greater prevalence of patient deaths, (2) language problems, (3) use of traditional medicines, (4) difficulties with referrals, and (5) differences in work ethics and values.

There was a large degree of frustration and sadness over the high prevalence of infant and childhood deaths at the rural facilities. Witnessing the death of babies and children was a disturbing occurrence for participants that was met with shock, disbelief and horror, as expressed in the following quote:

'I hadn't quite realised how crazy the HIV would be ... or young people being really sick, and children dying. In the UK, if a child dies in the hospital everyone gets therapy and it was a real shock on my first on call being called to a dead baby. I was like "My god, it's a dead baby", that just doesn't happen in the UK.' (Female doctor, Eastern Cape, 2010 Deanery candidate)

A second frustration was associated with the language barrier between the English speaking doctors and their predominately Zulu-speaking patients. A number of the doctors reported that vital patient information was 'lost in translation' during patient consultations. They believed that this resulted in four important consequences: (1) it limited their ability to give their patients the care they needed, (2) it created 'a real distance' between them and their patients, (3) it made them rely more on their clinical and examination skills, and (4) it could result in them practicing a paternalistic form of medicine with their patients.

The use of traditional medicine or home remedies was another source of frustration. Six doctors shared experiences of treating children and babies who had been given enemas with dishwashing liquid by their carers. Three doctors had also treated children who had been lashed by sangomas or who had had petrol poured down their throats. The frustration expressed by two doctors in the following quotes intimates a sense of helplessness in such situations. The quotes also allude to their perceived position as being relegated to 'observers', where they could only 'watch' their child patients suffering:

'It's incredibly hard, you watch babies die as a result ... . what was a healthy baby dying as a result of having been given something; that they have done because they think it will make their child better.' (Female doctor, northern KZN, 2010 Deanery candidate)

Another participant supported the above finding by stating that:

'I feel like standing there with my white skin and my British accent and saying "Please stop using your traditional medicine" because I've now personally watched 20 babies die, "Please stop doing that" ... but I just think my words have no weight whatsoever in that.' (Female doctor, northern KZN)

According to six doctors, frustration and disappointment was also caused by referral difficulties. Referral difficulties and delays often resulted in patients, including babies, dying in transit or before referral as a result of not receiving the necessary operations or treatment at tertiary hospitals. Four doctors admitted that their attempts to arrange referrals to tertiary hospitals often made them feel that it was a negotiation, like they were a 'second hand salesman', and very unsupported by the tertiary hospitals, a reality that 'was not an easy thing to adjust to'.

The last sub-group of frustrating experiences centered upon the perceived differences in work ethic and values between 
the British doctors and their South African counterparts. The UK doctors were more inclined to want each individual to accept personal responsibility for their mistakes or problems, whilst they believed that their South African colleagues had a culture of collective responsibility and a tendency to shift blame, and that frustrated them endlessly. In addition, three doctors stated that the poor work ethic demonstrated by some of the staff at their facilities was 'quite depressing' and that the focus on patient care was not as high as it should be. This latter belief was based on observations of health staff keeping the wards as low as possible and failing to include patients in their treatment decisions.

\section{Ethical considerations}

Ethical approval for the present study was obtained from the University of KwaZulu-Natal Biomedical Research Ethics Committee and the provincial Department of Health. Africa Health Placements (AHP) and the London GP Deanery head of the OOPE gave their permission for the researchers to conduct the study.

All current and 2010 Deanery candidates, as well as the individuals involved in the OOPE, were informed about the study, what their participation would entail and the voluntary nature of their participation before being asked to participate. Each interviewee was given an informed consent form to sign that included details about the study. These consent forms were sent and returned via email before the telephonic interviews. Everyone who was approached about the study agreed to be interviewed either telephonically or face-to-face.

Face-to-face interviews were conducted in private rooms at the hospitals. Confidentiality was ensured through the use of generic participant identifiers in the quotes provided. Electronic copies of the interviews and written transcripts are being stored under lock and key at the Health Economics HIV and AIDS Research Division (HEARD) offices, and are only accessible to the researchers involved in the study who are bound by confidentiality agreements.

Every participant was provided with a copy of the project report on the completion of the study, as adhering to good ethical practice (Gibbs 2007).

\section{Trustworthiness Reliability}

As one researcher was assigned to the analysis of the qualitative findings, inter-coder reliability could not be used to verify the consistency of the codes used. Instead, transcription checking and the use of constant comparisons to prevent definitional drift in the application of codes (Gibbs 2007) were used to ensure reliability of the findings. The written transcriptions were checked at least twice by the transcriber. The researcher also checked portions of the original transcripts to ensure their accuracy. To guard against definitional drift in the coding process the researcher developed coding definitions for each of the codes to ensure the consistent application of codes across transcripts and at different stages of the analysis.

\section{Validity}

Techniques outlined by Gibbs (2007), including constant comparisons and the provision of evidence, were used by the researchers to ensure the validity of the findings. The researcher analysing the data attempted to ensure that the codes developed from the data were consistently and accurately applied throughout the analysis to ensure that passages of text that were similar in nature were coded with the same codes. As suggested by Gibbs (2007), this process involved codes being developed from one text that were then compared across cases and revised where necessary. Hence, each transcript was initially coded and returned to later after all the transcripts had been read to recode where necessary. The researcher also looked for variations in the data, or negative case analysis, which were then examined in more detail to understand why the variation occurred (Gibbs 2007).

According to Gibbs (2007), 'a good, reflexive research report will demonstrate clearly how it is grounded in the data collected and interpreted'. Thus, the use of quotes provides the readers with an understanding of how the researchers came to their interpretations and conclusions in order for the readers and scientific community to decide whether the data is valid or not (Ryan \& Bernard 2003).

To present a more accurate and credible account of the data, the number of participants who raised, supported or agreed on the specific themes and sub-themes in question, as already presented, were indicated where possible. Gibbs (2007) recommends this when reporting qualitative findings to guard against the over-generalisation of the qualitative findings.

\section{Discussion}

This study sought to explore the work experiences of a group of British doctors during their OOPE in rural health facilities in SA, as well as the factors influencing their decisions to work in SA. These doctors had various reasons for coming to SA. The most common reasons related to the type of diseases and advanced pathologies that they would encounter, the challenge and professional growth the OOPE offered them, and the structure of the work environment that would confer on them greater responsibility and autonomy in comparison to similar positions in the NHS in the UK. Negative views about the heavy hierarchical structures within the NHS, and how these constrained opportunities for learning and development, were commonly reported. In contrast, the opportunity to be challenged and inspired in their work, and the sense of excitement practicing medicine in a developing context, were central to what the doctors had hoped their work experience in SA would entail. 
The doctors' experiences of their OOPE were often expressed in relative extremes of good and bad, or highs and lows. Their work experience appeared to enhance the generalist and/or specialist interface; improving their knowledge and competencies in specific areas of speciality, whilst also demanding that they be ready to attend to all medical cases that arrived at their health facility. The less hierarchical working environment created specialisation in managing particular patient cases, such as caesarean sections and opportunistic infections in HIV and/or AIDS cases. The structure of the work environment, even though drastically different from what they were familiar with in the UK, was positively embraced.

Generalist skills and competencies were enhanced by three things: (1) working at rural district hospitals that traditionally service large catchment populations, offering a variety of generalist services with limited health staff; (2) frequent rotation between wards; and (3) the personal learning activities undertaken by the doctors.

Each doctor recounted experiencing medical cases and challenges that exceeded their current knowledge and competency base. Their process of learning how to cope with these situations generally involved two things: (1) internal coping skills that were nourished by a high level of clinical confidence or that required a 'perspective change'; and (2) adaptation through active, constructive responses, such as initiating staff training or research studies. The latter response resulted in activities that added value to the operation and staff at their health facilities.

There was recognition that some of the frustrations the doctors experienced were universal and not unique to the South African healthcare system. Other frustrations such as resource shortages, traditional medicine, work ethic and values, difficulties with referrals and language problems, to some extent, were described at odds with their experience in the UK. Whilst some doctors attempted to learn fundamental Zulu words, and some advised patients about the dangers of traditional medicine and even set up a research study to address it, most felt unable to make significant progress towards addressing these challenges.

An integral part of the doctors' work experience, and their development and maturity, was the resource shortages they were exposed to at the facilities, the reality of which remained very difficult to adjust to. Resource shortages had implications for the way in which they viewed themselves, treated and cared for patients and made clinical decisions. Although they prized the greater autonomy and responsibility, this also placed them in a position of having to make extremely difficult decisions about their patients' level of care and treatment.

\section{Practical implications}

The positive benefits of temporary migration afforded by time-limited placements are obscured in the literature by an overwhelming focus on the negative impacts of emigration for host and sending countries. There are, however, positive benefits of temporary migration for the host countries facing significant skills shortages, like SA, who can tap into this supply of labour (Sriskandarajah 2005).

The findings of the present study have practical implications for the further development of programmes that aim to fill vacant posts in rural hospitals around SA with foreign doctors. They provide some evidence to attest to these programmes' potential to benefit both the host facility and the foreign doctors assigned to it. The findings also demonstrate that there are doctors in the UK, and perhaps in other countries, who, if given the opportunity through a formalised programme, would value temporary work assignment to rural health facilities in SA for some of the reasons this paper has highlighted.

Furthermore, it should be noted that the Deanery candidates' high work ethic, enthusiasm for professional learning and development, emphasis on patient-centered care and willingness to accept responsibility for their mistakes could enrich the work environments of rural health facilities where low levels of staff morale, motivation and job dissatisfaction are often rife (Witt 2009; Mills et al. 2011; Klopper et al. 2012; Faye et al. 2013). The source of frustrating experiences for the British GP trainees and the challenges encountered as a result of resource shortages should be addressed within the orientation and support processes that occur prior to their departure and during their stay in SA, to better prepare foreign doctors for working in rural district hospitals.

\section{Limitations}

The present study is limited by the small sample size of doctors, and by the fact that it represents the experiences of doctors within one time-limited programme in one country. The assessment of the value that the doctors' brought to their health facilities is limited, as facility managers and their fellow South African staff were not interviewed. Nonetheless, valuable insights are provided as to the experiences of this group of doctors in SA.

\section{Recommendations}

The use of time-limited placements to reduce vacancies in rural areas should be given more consideration by government. The London Deanery OOPE with the AHP is an example of a partnership between a foreign medical school and a local organisation that is succeeding in bringing in a sustainable, annual inflow of foreign doctors to rural areas of SA. Given the positive work experiences articulated by the participants, health facilities and government officials in SA should forge good relations with the foreign doctors and OOPE programme personnel to encourage the future return of these participants and/or the filling of other vacant posts by programme candidates. Furthermore, the growing number of vacant posts in rural hospitals provides motivation for the future scale-up of the programme 
to other Deaneries in the UK and other provinces in South Africa.

The sustainability of the programme also depends on the experience and learning received by the doctors during their OOPE, underscoring the importance of senior staff and supervisors providing the necessary support and guidance for the doctors' professional development and adjustment. Last, difficulties in adjusting to the different work ethic, culture of blame and responsibility, high rates of patient and infant mortality and the differential role of the patients in their treatment decisions and care should be pre-empted by senior staff and supervisors who can provide the necessary orientation and support. Resident staff should also recognise the value that foreign doctors can bring to their facilities, as well as their fresh perspective and attitude towards patient care that could enrich the work environment of these facilities.

\section{Conclusion}

Although little research has been undertaken to look at the possible benefits of temporary placements for host and sending healthcare systems, these findings do suggest that temporary placements of UK doctors in rural hospitals in SA can enhance the clinical skills and competencies of these doctors. Exposure to new and unfamiliar medical cases, a greater level of autonomy and decision-making authority, and resource shortages that forced greater reliance on clinical skills and judgment contributed to their professional development.

Furthermore, the majority of this cadre of British doctors had an affinity for international health and work experience abroad. They endeavored to add value to their health facility and fellow staff and where it was within their power to bring about constructive change, they attempted to do so.

Future research should focus on exploring time-limited placements, such as the London Deanery OOPE, among a larger sample of health professionals and combine this with interviews with resident health facility staff and patients. This would give a fuller and clearer picture of foreign health workers' contributions to the health system and challenges that they face whilst in South Africa.

\section{Acknowledgements}

The study was commissioned by the International Organisation for Migration and funded by the European Union. The researchers would like to acknowledge the London GP Deanery and AHP for their permission for us to conduct the study among the doctors involved in their OOPE.

\section{Competing interests}

The authors declare they have no financial or personal relationship(s), which may have inappropriately influenced them in the writing of this article.

\section{Authors' contributions}

C.R. (University of KwaZulu-Natal) was the project leader, C.R. and G.G. (University of KwaZulu-Natal) developed the research methodology, C.R. and O.E. (University of KwaZulu-Natal) wrote the first draft of the article, C.R. and G.G. made final revisions to the article.

\section{References}

Awases, M., Gbary, A., Nyoni, J. \& Chatora, R., 2004, 'Migration of Health Professionals in Six Countries: A Synthesis Report' World Health Organization WHO-AFRO DHS Brazzaville, viewed 14 March 2014, from http://www.afro.who. int/dsd/migration6countriesfinal.pdf

Bangdiwala, S., Fonn, S., Okoye, O. \& Tollman, S., 2010, 'Workforce Resources for Health in Developing Countries', Public Health reviews 32 (1), 296-318.

Bezuidenhout, M., Joubert, G., Hiemstra, L. \& Struwig, M., 2009, 'Reasons for doctor migration from South Africa', SA Family Practice 51(3), 211-215.

Bogdan, R. \& Biklen, K., 1982, Qualitative research for education: An introduction to theory and methods, 2nd edn., Allyn and Bacon, Boston.

Breier, M. \& Wildschut, A., 2006, Doctors in a divided society, The profession and education of medical practitioners in South Africa, HSRC Press, Cape Town.

Breier, M., Wildschut, A. \& Mgqolozana, T., 2009, Nursing in a new era: The profession and education of nurses in SA, HSRC Press, Cape Town.

Clemens, M. \& Pettersson, G., 2008, 'New Data on African Health Professionals Abroad', Human Resources for Health, 6 (1).

Cullinan, K., 2006, Health services in SA: A basic introduction, viewed 24 March 2014, from http://www.health-e.org.za/uploaded/ cb1f388f3b351708d915c12cfb4fc3cf.pdf.

Delobelle, P., Rawlinson, J., Ntuli, S., Malatsi, I., Decock, R. \& Depoorter, A., 2011 'Job satisfaction and turnover intent of primary healthcare nurses in rural South Africa: a questionnaire survey', Journal of Advanced Nursing, 67 (2), 371-383.

Department of Health, 2002, A district hospital service package for South Africa: A set of norms and standards', viewed 24 March 2014, from http://www0.sun.ac.za/ ruralhealth/ukwandahome/rudasaresources2009/DOH/DRAFT\%20DISTRICT\%20 HOSPITAL\%2OPACKAGE.pdf.

Department of Health, 2011, HRH Strategy for the Health Sector: 2012/13 - 2016/17 Department of Health, Pretoria.

Dovlo, D., 2007, 'Migration of Nurses from Sub-Saharan Africa: A Review of Issues and Challenges', Health Serv Res, 42(3), 1373-1388, doi: 10.1111/j.14756773.2007.00712.x.

Econex, 2010, 'The human resource supply constraint: The case of doctors', Health Reform Note 8, November 2010.

Essack, S., 2013, 'Human Resources for Health: Challenges and Solutions', Public Health Association of South Africa, KwaZulu-Natal.

Faye, A., Fournier, P., Diop, I., Philibert, A., Morestin, F. \& Dumont, A., 2013 'Developing a tool to measure satisfaction among health professionals in subSaharan Africa', Human Resources for Health 11 (30), 1-11.

George, G. \& Reardon, C., 2013, 'Preparing for export? Medical and nursing student migration intentions post-qualification in South Africa', African Journal of Primary Health Care Family Medecine 5 (1), 1-9.

George, G., Quinlan, T. \& Reardon, C., 2009, 'Human resources for health: A needs and gaps analysis of HRH in SA', Health Economics and HIV \& AIDS Research Division (HEARD), 2-70.

George, G., Quinlan, T., Reardon, C. \& Aquilera, J., 2012, 'Where are we short and who are we short of? A review of the Human Resources for Health in South Africa', Health SA Gesondheid 17 (1), 1-7.

Gibbs, G., 2007, Analysing qualitative data, The Sage Quality Research Kit, Sage Publications, California.

Hamilton, K. \& Yau, J., 2004, The global tug-of-war for health care workers, Washington, DC: Migration Policy Institute, viewed 17 March 2010, from http:// www.migrationinformation.org/Feature/print.cfm?ID=271

Hontelez, J., Newell, M., Bland, R., Munnely, K., Lessells, R. \& Bamighausen, T., 2012 'Human Resource Needs for Universal Access to Antiretroviral Therapy in South Africa: A Time and Motion Study', Human Resources for Health 10 (1), 39-50.

International Organization for Migration (IOM), 2011, National Profile of Migration of Health Professionals, South Africa, MoHProf, Brussels.

Jacques, P., Reid S., Chabikuli, O. \& Fehresen, S., 1998, 'Developing appropriate skills for rural doctors: procedural skills of rural doctors in South Africa', Health Systems Trust, viewed 13 March 2014, from http://www.healthlink.org.za/uploads/files/ appskils.pdf

Kingma M., 2008, 'Nurses on the Move: Historical Perspective and Current Issues', Online Journal of Issues in Nursing 13 (2), 1-13.

Kinoti, S., 2003, 'Commissioned Paper Joint Learning Initiative', Africa Working Group, September 2003.

Klopper, H., Coetzee, S., Pretorius, R. \& Bester, P., 2012, 'Practice environment, job satisfaction and burnout of critical care nurses in South Africa', Journal of Nursing Management 20, 685-695.

Lloyd, B., Sanders, D. \& Lehmann, U., 2010, 'Human Resource Requirements for National Health Insurance', ch. 17, in S. Fonn \& A. Padarath (eds.), South African Health Review 2010, Health Systems Trust, Durban. 
Long, L., 2007, Facilitation of the Recruitment and Placement of Foreign Health Care Professionals to Work in the Public Sector Health Care in South Africa, Report for International Organisation for Migration (IOM), Pretoria.

Mills, E., Kanters, S., Hagopian, A., Bansback, N., Nachega, J., Alberton et al., 2011, 'The Financial Cost of Doctors Emigrating from sub-Saharan Africa: Human Capital Analysis', BMJ, 343.

Moloi, L., 2013, 86\% doctor vacancy rate in Limpopo, media release, South African Institute of Race Relations, viewed 09 September 2013, from http://www.sairr org.za/media/media-releaseswww.sairr.org.za

Reid, S., 2001, 'Crisis in rural South Africa', Journal of South Afr Family Practice 23 (3), 17-20'.

Rosen, S., Sanne, I., Collier, A. \& Simon, J., 2005, 'Rationing Antiretroviral Therapy for HIV/AIDS in Africa: Choices and consequences', PLoS Med 2(11), 1098-1104.

Ryan, G. \& Bernard, R., 2003, 'Techniques to identify themes', Field Methods 15 , 85-109.

Ryan, G. \& Bernard, R., 2003, 'Techniques to identify themes', Field Methods 15, 85-109. http://dx.doi.org/10.1177/1525822X02239569

Sanders, D. \& Lloyd, B., 2009, Major and focussed investment in health personnel is needed to solve the Health Care Crisis, viewed 21 October 2013, from http:// www.amandlapublishers.co.za/special-features/the-nhi-debate?start $=15$

Shisana, O., Hall, E., Maluleke, K., Stoker, D., Schwabe, C. \& Colvin, M., 2004, 'The Impact of HIV/AIDS on the Health Sector: National Survey of Health Personnel, Ambulatory and Hospitalised Patients and Health Facilities', viewed 14 March 2014, from http://www.hsrchsrcpublishers.ac.za
Sriskandarajah, D., 2005, Migration and Development, Paper prepared for the Policy Analysis and Research Programme of the Global Commission on International Migration (GCIM), viewed 21 July 2013, from http://www.gcim. org/mm/File/Thematic\%20Study\%204.pdf

Stilwell, B., Diallo, K., Zurn, P., Vujicic, M., Adams, O. \& Poz, M., 2004, 'Migration of health-care workers from developing countries: Strategic approaches to its management', Bulletin of the World Health Organization 82 (8), 595-601.

Tawfik, L. \& Kinoti, S., 2006, 'The impact of HIV/AIDS on the health workforce in developing countries', Background paper prepared for the world health report, WHO, viewed 14 March 2014, from http://www.who.int/hrh/ documents/Impact_of_HIV.pdf

Tjadens, F., Weilandt, C. \& Eckert, J., 2012, Mobility of Health Professionals: Health systems, work conditions, patterns of health workers' mobility and implications for policy makers, MOHProf summary report, viewed 12 September 2013, from http://www.mohprof.eu/LIVE/DATA/National_reports/ national_report_Summary.pdf

Wildschut, A. \& Mgqolozana, T., 2009, 'Nurses', in J. Erasmus \& M. Breier (eds.), Skills shortage in South Africa: Case studies of key professions, HSRC Press, Cape Town.

Witt, J., 2009, 'Addressing the Migration of Health Professionals: The Role of Working Conditions and Educational Placements', BMC Public Health 1 (9), $1-5$.

World Health Organization (WHO), 2006, Working Together for Health, the World Health Report, Geneva, Switzerland. 